\title{
KEPEMIMPINAN KEPALA SEKOLAH DAN KINERJA GURU TERHADAP PRESTASI SISWA
}

\section{ARTIKEL}

"Diajukan untuk Memenuhi Tugas Mata Kuliah Psikologi Manajemen”

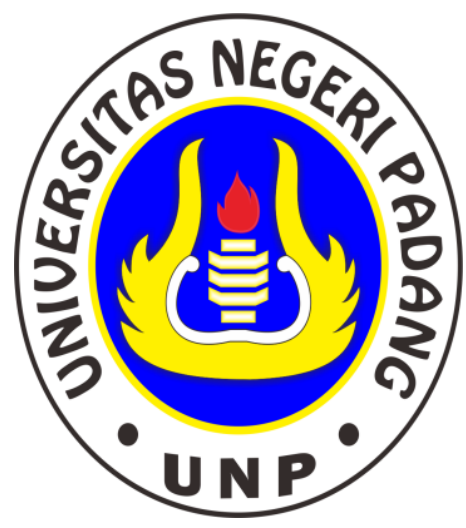

Oleh :

Silvy Utari Wahyuni

NIM. 17002031

JURUSAN ADMINISTRASI PENDIDIKAN

FAKULTAS ILMU PENDIDIKAN

UNIVERSITAS NEGERI PADANG 


\title{
KEPEMIMPINAN KEPALA SEKOLAH DAN KINERJA GURU TERHADAP PRESTASI SISWA
}

\author{
Artikel \\ Psikologi Manajemen \\ Silvy Utari Wahyuni \\ Universitas Negeri Padang \\ Indonesia \\ E-mail: silvyutariwahyuni1310@gmail.com
}

\begin{abstract}
ABSTRAK
Tujuan dari artikel ini adalah untuk mengetahui seberapa besar pengaruh kepemimpinan sekolah dan kinerja guru terhadap prestasi belajar siswa. Guru berperan penting bagi keberhasilan siswa. Hingga dipengaruhi oleh dua faktor sangat mempengaruhi prestasi belajar siswa terutama hasil Ujian Sekolah.

Artikel ini bertujuan untuk menjelaskan tentang kepemimpinan guru dalam menyelesaikan tugas mereka di kelas yang menganalisis fungsi pendidikan dan pelajaran yang menyenangkan instruksional. Kepemimpinan guru dalam mendidik dapat dilakukan dengan cara (a) memberi motivasi kepada guru; guru harus memotivasi siswa dalam proses perubahan perilaku mereka menjadi perilaku yang lebih baik dan lebih baik. (b) Untuk membimbing siswa; Mereka harus membimbing siswa yang berperilaku tidak sesuai dengan norma. (c) Ke arah; Guru harus mengendalikan dan mengarahkan kegiatan siswa, sehingga siswa tidak akan berperilaku seperti itu untuk berbenturan dengan norma. Kepemimpinan guru secara intructional dapat dilakukan dengan : (a) Memberi motivasi kepada siswa; guru harus memotivasi siswa dalam proses pengajaran dengan teknik memilih dan menggunakan metode pengajaran variasi. (b) Kepada Membimbing siswa; Guru harus membimbing siswa meningkatkan prestasi mereka dengan teknik pelatihan langsung dan bantuan dalam latihan, (c) Ke arah; Guru harus bisa mengarahkan siswa dalam proses pembelajaran dengan jelas, sehingga mudah dipahami.
\end{abstract}

Kata Kunci: Kepemimpinan, kinerja guru, prestasi akademik, kepemimpinan guru, pelaksanaan tugas 


\section{PENDAHULUAN}

Kepemimpinan adalah sebuah proses mempengaruhi orang lain agar melaksanakan tugas-tugas organisasi secara suka rela kepada bawahannya untuk senantiasa produktif. Oleh karena itu keberadaan seorang pemimpin dalam suatu organisasi dirasakan sangat mutlak untuk menjadi nahkoda bagi bawahannya. Kepemim-pinan yang efektif merupakan prasyarat vital bagi kelangsungan hidup dan keberhasilan suatu organisasi. Demikian juga dalam dunia pen-didikan, pendidikan adalah suatu sistem, dimana antara komponen satu dengan yang lain saling mempengaruhi untuk mencapai tujuan. Dalam hal ini komponen guru dan kepala sekolah memegang peranan penting dalam pencapaian tujuan pendidikan. Perilaku guru akan dipengaruhi oleh perilaku kepala sekolah. Oleh karena itu kepemimpinan kepala sekolah yang baik akan mempengaruhi perilaku guru menjadi baik juga, misalnya menjadi percaya diri, loyal, dan termotivasi untuk melaksanakan tugas secara optimal.

Ada 10 faktor yang mempengaruhi semangat kerja seseorang dalam melaksanakan tugas yaitu: 1) kesiapan kerja 2) kondisi kerja 3) organisasi kerja 4) kepemim-pinan 5) gaji 6) kesempatan 7) mengemukakan ide 8) kesempatan mempelajari tugas 9) jam kerja 10) kemudahan kerja. Sedangkan hasil penelitian Hutchison menemukan ada 6 faktor yang mempengaruhi turunnya semangat kerja pegawai, khususnya guru yaitu: 1) dukungan teman sejawat 2) hubungan dengan pimpinan gaji 4) pekerjaan dan tanggug jawab 5) kurangnya kesempatan berkembang 6) kondisi dan beban kerja yang berlebihan. Dari Hasil penelitian tersebut di atas menunjukkan salah satu yang dapat mempengaruhi kinerja seseorang diantaranya adalah kepemimpinan,

Dari pendapat tersebut bisa disimpulkan bahwa kepemimpinan kepala sekolah sangat berperan dalam meningkatkan semangat kerja guru dalam melaksanakan tugasnya sehingga dapat tercipta kondisi kerja yang harmonis dan menyenangkan. Dengan demikian guru akan lebih bersemangat dalam membina siswa baik akademik maupun non akademiknya.

Banyak faktor yang menentukan keberhasilan pendidikan di sekolah, salah satunya adalah guru. Guru menempati posisi yang sangat penting dalam pencapaian tujuan pendidikan. Tugas guru tidaklah mudah seperti yang dibayangkan, namun sebaliknya tugas dan peranan guru sebagai pendidiksebenarnya sangat komplek. Tugas guru mencakup banyak hal antara lain : guru sebagai pengajar memimpin kelas, pembimbing, pengatur lingkungan, partisipan, ekspeditor, perencana, supervisor, motivator dan konselor.

Peranan guru dalam dunia pendidikan amatlah penting, oleh karena itu guru harus mempunyai tanggung jawab penuh atas pekerjaannya. Tugas guru adalah tugas pedagogis yaitu membantu membimbing dan memimpin, bukan hanya semata-mata mengontrol dan mengkritik. Di dalam suatu sit uasi pengajaran, gurulah yang memimpin dan bertanggung jawab penuh atas kepe-.mimpinan yang dilakukannya. 
Salah satu peranan guru dalam suatu kelas adalah sebagai seorang pemimpin. Kepemimpinan yang dilakukan oleh seorang guru dapat digunakan untuk mempengaruhi, mendorong, mengajak, menuntun, menggerakkan dan kalau perlu memaksa siswa agar ia mau menerima pengaruh itu selanjutnya berbuat sesuatu maksud atau tujuan tertentu. Oleh karena itu seorang guru dalam kepemimpinannya harus dapat menjadi seo rang pembimbing dan sebagai pelatih, sebagai orang yang dapat memberikan kesempatan kepada siswanya untuk bertindak, berpartisipasi dan memberikan petunjuk, nasehat, apakah tindakan mereka itu benar atau tidak. kepemimpinan adalah suatu proses guru mempengaruhi kegiatan siswa supaya teratur dalam kegiatan pembelajaran.. Kepemimpinan guru dalam proses pembelajaran dapat dilihat dari guru yang mampu untuk mengarahkan sis wanya agar mau memperhatikan guru yang sed ang memberikan materi pelajaran.Adapun kegiatan kepemimpinan diantaranya dalam hal memotivasi, membimbing, mengarahkan, menuntun, mengajak dan sebagainya.

\section{PEMBAHASAN}

\section{Pengertian Kepemimpinan}

Pengertian kepemimpinan adalah hubungan antara seorang pemimpin dalam mempen garuhi orang lain untuk bekerja sama secara sadar dalam hubungan tugas untuk mencapai tujuan yang diinginkan pemimpin. kepemimpinan sebagai proses pemimpin menciptakan visi, mempengaruhi sikap, perilaku, pendapat, nilai-nilai, norma dan sebagainya dari pengikut untuk merealisasi pengikut. kepemimpinan adalah proses mempengaruhi orang-orang sehingga mereka mau berusaha dengan sepenuh hati dan antusias untuk mencapai tujuan".

Dari pendapat ahli di atas, maka dapat ditarik kesimpulannya bahwa kepemimpinan merupakan kemampuan ya ng dimiliki seorang guru untuk mempengaruhi, menggerakkan, danmemotivasi siswanya agar mereka dengan semangat dan kesadaran yang tinggi mau berbuat dan menyumbangkan wak tu, tenaga, dan pikiran mereka dalam mecapai tujuan pembelajaran.

\section{Pengertian Kepemimpinan Guru}

Menurut (Ermita, 2015) dalam jurnalnya, Kepemimpian berarti kemampuan dan k esiapan yang mengajak, menuntun, menggerakkan, mengarahkan, dan kalau perlu memaksa orang atau kelompok agar mereka menerima pengaruh ters ebut dan selanjutnya berbuat sesuatu yang dapat membantu tercapainya suatu tujuan tertentu yang telah ditetapkan".

Sedangkan yang dimaksud dengan guru menurut Mulyasa (2007:37) "adalah pendidik, yang menjadi tokoh, panutan, $\mathrm{d}$ an identifikasi bagi para peserta didik, dan lingk ungannya". Selanjutnya yang dimaksud dengan "guru yaitu salah satu komponen 
manusiawi dalam proses belajar mengajar, yang iku t berperan dalam usaha pembentukan sumber daya manusia yang potensial di bidang pembangunan".

Dari kedua pendapat di atas maka dapat disimpulkan bahwa yang dimaksud dengan kepemimpinan guru adalah kemampuan yang dimiliki oleh seorang guru untuk mengajak, mengarahkan, dan bisa saja memaksa siswa untuk mau menerima pengaru $\mathrm{h}$ dan berbuat dalam mencapai tujuan pendidika n yang telah ditetapkan sebelumnya.

\section{Pentingnya kepemimpinan}

Menurut (Ermita, 2015) dalam jurnalnya Keberhasilan sekolah dalam mencapai tujuan pendidikan sangat di tentukan oleh keandalan seorang guru sebagai pe mimpin dalam kegiatan pembelajaran. Guru sebagai orang yang memiliki harapan tinggi bagi sisw a terhadap tugas dan fungsinya dalam menentuk an tujuan pembelajaran yang dipimpinnya. Sebag ai seorang pemimpin, guru harus dapat mempeng aruhi aktivitas siswanya dalam rangka pencapa ian tujuan sekolah. Kepemimpinan merupakan aspek yang sangat penting dalam suatu organisasi karena keberhasilan

\section{Kepemimpinan Guru dalam Mendidik}

Menurut (Ermita, 2015) dalam jurnalnya Mendidik diartikan "sebagai suatu usaha untuk mengantarkan anak didik kearah kedewasaan ya baik secara jasmani maupun rohani”. Mendidik adalah memelihara dan memberi latihan (ajaran, pimpinan) mengenai akhlak dan kecerdasan pikiran.

Guru adalah pendidik, yang menjadi tokoh, panutan dan identifikasi bagi peserta didik dan lingkungannya. Oleh karena itu guru harus memiliki standar kualitias priba di tertentu, yang mencakup tanggung jawab, wiba wa, mandiri dan disiplin. Untuk menjalankan perannya sebagai pendidik dalam proses pembelaja ran, seorang guru perlu memberi contoh-contoh penerapan praktis kepada anak didik, menggunak an istilah-istilah yang sederhana tapi jelas serta m enanyakan soal-soal yang penting supaya apa yang dipelajari dapat lebih mudah dipahami. Disampin g itu, guru juga perlu memberikan kesempatan kepada anak didiknya untuk mau mengungkapkan apa yang menjadi kebutuhan dan kesulitan mereka dalam belajar. Dari pengungkapan ini akan terlihat kesulitan mereka sehingga guru pun bisa menyajikan bahan yang sesuai dengan kebutuhan anak didik. Selain itu, cara ini juga memungkinkan guru untuk dapat menolong anak didik yang mengalami kesulitan dalam belajar.

Seorang kepala sekolah wajib memberikan motivasi dan upaya pembinaan terhadap guru, baik melalui supervisi akademik, klinis, maupun pemberian reward kepada guru agar terbangun iklim yang menyenangkan, saling asah, asih dan asuh, sehingga kinerja guru meningkat dan prestasi siswa akan meningkat pula, hal ini sesuai dengan hasil penelitian Hersey yang menyatakan bahwa salah satu yang dapat mempengaruhi kinerja seseorang diantaranya adalah kepe-mimpinan dan juga hasil penelitian Sylvia dan Hutchiston 
mengatakan bahwa salah satu penyebab turunnya semangat kerja pegawai adalah hubungan dengan pimpinan.

\section{PRESTASI BELAJAR}

Menurut (Lestari, 2007) dalam juralnya, Prestasi belajar merupakan tingkat pemahaman yang dimiliki siswa dalam menerima informasi-informasi yang diperoleh dalam proses belajar mengajar. Prestasi belajar seseorang sesuai dengan tingkat keberhasilannya dalam mempelajari materi pelajaran yang dinyatakan dalam bentuk nilai pada rapor untuk setiap mata pelajaran setelah mengalami proses belajar mengajar. Prestasi belajar siswa dapat diketahui setelah diadakan evaluasi. Hasil dari evaluasi dapat memperlihatkan tentang tinggi atau rendahnya prestasi belajar. Sehingga dapat disimpulkan bahwa apabila kepuasan kerja guru terhadap kepemimpinan kepala sekolah meningkat maka kinerjanya akan meningkat pula dan selanjutnya akan berpengaruh positif terhadap prestasi belajar siswanya.

\section{SIMPULAN DAN SARAN}

Berdasarkan dari latar belakang dan hasil pembahasan, maka dapat disimpulkan bahwa kepemimpinan Kepala Sekolah memiliki pengaruh yang signifikan terhadap kinerja guru, namun tidak ada pengaruh yang signifikan terhadap prestasi belajar siswa.

Kepemimpinan merupak an kemampuan yang dimiliki seorang guru untu $\mathrm{k}$ mempengaruhi, menggerakkan, dan memotivasi siswanya agar mereka dengan semangat dan kesadaran yang tinggi mau berbuat dan menyu mbangkan waktu, tenaga, dan pikiran mereka dala m mecapai tujuan pembelajaran. Bila dikaitkan kepemimpinan dengan guru maka kepemimpin an guru adalah kemampuan yang dimiliki oleh seorang guru untuk mengajak, membimbing, memotivasi, mengarahkan dan bisa saja mem aksa siswa untuk mau menerima pengaruh dan berbuat dalam mencapai tujuan pendidikan yang telah ditetapkan sebelumnya.

Tugas umum seorang guru adalah tugas personal, tugas sosial da $\mathrm{n}$ tugas profesionalnya. Sedangkan tugas guru sebagai profesi yaitu mendidik, dan mengajar. Kepemimpinan guru dalam melaksanakan tugasnya dapat dilihat da ri kepemimpinan guru dalam mendidik dan kep emimpinan guru dalam mengajar. Kepemimpinan guru dalam mendidik dan mengajar dapat dilakukan guru dengan cara memotivasi, membimbing dan mengarahkan siswa. 
Dari kesimpulan tersebut di atas maka disampaikan beberapa saran antara lain:

Hendaknya kepala Sekolah dapat membangun kerjasama yang positif melalui pembinaan dan pemberian motivasi kepada guru agar kinerja guru meningkat, sehingga prestasi belajar siswa akan meningkat pula.

Kepala sekolah hen daknya mampu memberikan konsep, pengetahuan, dan pengalaman bagaimana cara memimpin yang baik sehingga gu ru mampu untuk menerapkan kepemim pinannya dalam kegiatan pembelajaran sehingga tujuan dapat tercapai.

Guru sebagai pemimpin dalam kegiatan pembelajaran yang mempunyai peran yang sangat kompleks terutama sebagai pendidik dan pengajar harus lebih ditingkatkan lagi kepemimpinannya karena gurulah yang mempunyai peran yang sangat besar dalam dunia pendidikan. 


\section{DAFTAR RUJUKAN}

Ermita. (2015). Kepemimpinan Guru Dalam Pelaksanaan Tugasnya di Kelas. Jurnal Ilmiah Ilmu Pendidikan, XV(2), 31-41.

Lestari, S. (2007). Pengaruh Kepemimpinan Kepala Sekolah dan Kinerja Guru Terhadap Prestasi Siswa. Jurnal Ilmiah Ilmu Pendidikan, 32(2), 127-132. 